\title{
Framing British 'jihadi brides': Metaphor and the social construction of I.S. women
}

\begin{abstract}
This article considers how mainstream newspapers metaphorically represented the British 'jihadi brides', women and girls who travelled to Syria to live in the self-declared 'Islamic State' (I.S.). Based on an analysis of 365 articles published between 2013 and 2018, the article demonstrates that three frequently occurring metaphors contributed to the construction of these women and I.S. in general, representing them as natural, biological and supernatural forces. These metaphors served to convert a new phenomenon into a knowable form, but in doing so evoked homogenizing and dehumanizing representations that structured the scope of possibilities for responding to the problem of the 'brides'. Ultimately, these social constructions had material consequences, as demonstrated by the mood of indifference among policy-makers to the fate of British I.S. fighters and their families following the fall of the 'caliphate'.
\end{abstract}

Keywords: jihadi brides, women, Islamic State of Iraq and Syria, metaphor, constructivism

\section{Introduction}

In October 2017 it was reported that prominent British 'jihadi bride' Sally Jones had been killed by a CIA drone strike near the Iraqi/Syrian border in June of that year. Her 12-year old son, Jojo, had been with her at the time and was also killed, raising profound questions about the extra-judicial execution of militants and, most troublingly, whether the children of 'jihadi brides' were considered acceptable 'collateral damage'. The child's step-father, Junaid Hussain, had been assassinated by drone strike two years earlier. Having been placed on the Pentagon's 'kill list', Hussain had been careful to travel at all times with Jojo, using him as a 'human shield' to avoid the drones that monitored his movements, and the lethal strike occurred on one of the rare occasions 
that he was unaccompanied by the child. The strike that killed Sally Jones, however, went ahead despite Jojo's presence. What changed in the two years between the targeted killings of Hussain and Jones?

This article considers how such actions become possible from a social constructivist perspective, through an analysis of the framing of 'jihadi brides' in British newspapers. Most scholarship on the 'brides' has approached them through the prism of radicalization, ${ }^{1}$ focusing on the role of the internet in providing access to jihadist propaganda, ${ }^{2}$ promoting 'jihadi-cool' sub-cultures ${ }^{3}$ and enabling young women to develop close on-line friendships with individuals already based in I.S territory. ${ }^{4} \mathrm{~A}$ smaller, but growing, area of research considers how they were represented, emphasizing particularly the gendered assumptions that portrayed those who migrated as brainwashed, groomed, and lacking in agency. ${ }^{5}$ The present article builds on this work by analyzing metaphorical representations of the 'brides' in British newspapers, but it also goes further. By considering the consequences of these representations it offers an explanation as to how the increasingly hardline treatment of some 'jihadi brides', including the targeted killing of Sally Jones, became possible.

This study addresses two research questions: How were the British 'jihadi brides' metaphorically represented, and what courses of action were made possible or restricted as a result of these representations? The article proceeds by outlining constructivist approaches to the study of terrorism, and the specific contribution made by metaphor analysis. It then presents an analysis based on 365 articles published in UK newspapers between 2013 and 2018, which discusses three prominent metaphors that portrayed the 'brides', and I.S. more broadly, as natural, biological and supernatural forces. These expressions evoked natural disaster (e.g. waves and floods), toxicity (e.g. poison and viruses), vegetation (e.g. seeds and roots), and the supernatural (e.g. the 
enchantment of 'evil' jihadist men). While these metaphors sought to explain the novel phenomena of the 'brides', they contributed to the dehumanization of the women in question, structuring the range of possibilities for dealing with them. Specifically, these dehumanizing discourses contributed to creating new policy norms, including indifference to the fate of the 'brides', the relaxing of attitudes towards international law and the extra-judicial assassination of British subjects.

\section{The social construction of the 'brides'}

Constructivist approaches to terrorism emphasize that the terrorist act does not speak for itself. Rather, it is constituted through the language and practices that interpret it (as crime, an act of war, etc.), ${ }^{6}$ and as such it should be approached in the realm of discourse. Although terrorist acts and the people who perpetrate them are material realities, what these acts and subjects mean is a matter of social construction, and it is the discursive choices made by those who write and speak about terrorism that construct it in a particular way. The effects of these choices have been the subject of a number of studies that have sought to demonstrate how the language used to describe terrorism and terrorists structures the responses that are deemed necessary and those considered unthinkable. ${ }^{7}$

Scholarship on politically violent women has long noted that these constructions rely on gendered assumptions, emphasizing personal explanations for involvement, including family, romance and sexual assault, while downplaying political and ideological motivations. ${ }^{8}$ Reporting on female terrorists tends to highlight physical appearance, ${ }^{9}$ and frames that reproduce well-rehearsed plotlines such as 'the good girl gone bad" and "for the sake of love", eliding political and ideological commitment in favor of clichéd narratives. ${ }^{10}$ 
Representations of I.S. women in media discourse have been the subject of a number of recent studies. ${ }^{11}$ For example, Alice Martini considered how British broadsheet newspapers represented these women, arguing that their construction relied on gendered and neo-Orientalist tropes that infantilized the 'brides', homogenizing their desires and experiences, and portraying them as apolitical and without agency. ${ }^{12}$ The present article is similarly concerned with media constructions, however it differs in two key ways. First, Martini's focus on the representations within broadsheet newspapers offers a partial, and somewhat incomplete picture of the discourses circulating. Tabloid newspapers in the UK have a large readership, ${ }^{13}$ and excluding the discourses produced at these sites means omitting a significant site of meaning-making. Second, while Martini's study presents the key narratives that served to construct the 'brides', the consequences of such narratives are not interrogated, and this is important if we take seriously the constructivist position that the way we speak about things affects our material reality. ${ }^{14}$

My interest in this article is to understand how constructions made particular policy options more or less possible and, as such, the analysis presented here does not use gender as its primary analytical lens, focusing instead on metaphorical representations of I.S. women (including their relationship to the broader context of I.S.), and exploring the possibilities opened up by these, while at the same time identifying the gendered dynamics that structure these constructions. ${ }^{15}$ Understanding the ways in which the 'jihadi brides' were problematized through gendered discourses that denied their agency is important, but it is equally important to interrogate the possibilities that such constructions made space for. The present article attempts to foreground this concern by considering how journalists represented the 'brides' for 
public consumption, the metaphorical understandings that were central to this, and the implications of these framings.

\section{Metaphor and representation}

News frames function to define problems, diagnose causes, morally evaluate agents and recommend remedies. ${ }^{16}$ In doing so they elevate the salience of particular aspects of a perceived reality in a communicating text, collecting key concepts, phrases and images to prioritize and reinforce particular interpretations of events, by, for example, presenting events as terrorism, as opposed to insurgency, militancy, war, or crime. ${ }^{17}$ Metaphors are a useful tool in this framing process, providing a means of presenting complex new phenomenon in familiar ways by importing meaning from other domains.

Since metaphors work by transferring meaning, they can be understood to cognitively structure human understanding of a phenomenon by projecting knowledge about one domain onto another. ${ }^{18}$ In their classic work, Metaphors We Live By, Lakoff and Johnson give the example of the cultural practice of arguments, frequently metaphorically represented as war through expressions such as: I demolished her argument, her criticisms were right on target, she shot down all my claims. From this, they argue that metaphors operate as more than simply rhetorical flourishes; they

fundamentally structure our conceptual systems and how we think and act. ${ }^{19}$ Since mental models of the world are articulated through speech and writing, metaphorical cognitions can be located in discourse. It is important to note that the expressions associated with the metaphor 'argument is war' are not simply unrelated individual instances of a particular way of conceptualizing argumentation. Rather, a number of common expressions aggregate around the same conceptual schema of what is going on when individuals are engaged in an argument. For this reason, the frequency of metaphorical expressions alone does not tell us very much; however, when a number of 
different expressions point to the same conceptual metaphor, this suggests that a metaphorically structured cognitive schema is being articulated. ${ }^{20}$

Metaphors are particularly useful (and abundant) when humans are confronted with novel phenomena, serving as a means of reducing complexity and making the unfamiliar comprehendible by mapping the known onto the new. ${ }^{21}$ This process of recognizing similarities between two things leads people to assume other similarities, which in turn opens or constrains possibilities for action: what we (think we) know about a thing affects how we think it should be dealt with.

The present article is concerned with the social construction of the 'jihadi brides' in newspapers. As sites of meaning-making newspapers have a large audience and an important public role. Even in an age when circulation is dramatically declining, 40 per cent of people in the UK report that they get their ideas about the world from newspapers. ${ }^{22}$ There is wide scholarly agreement that the way an issue is framed in the media affects public and policy maker opinion, ${ }^{23}$ although it is often difficult to discern how and to what extent these influence support for particular actions. ${ }^{24}$ This article does not suggest that causality in any direct sense can be discerned from the metaphorical representations of the 'brides'. Rather, it is interested in how these representations made particular actions possible.

\section{Method}

Seven newspapers were included in this study, retrieved from ProQuest newsstand database and chosen based on their high circulation figures and an attempt to broadly balance between ideological position and tabloids and broadsheets: The Sun, and the Daily Mirror are tabloid newspapers (the former right-leaning and the latter leftleaning), while the Daily Mail is middle-market (here classified as a tabloid) and rightleaning. The Times and The Daily Telegraph are right-leaning broadsheets, while the 
Guardian and the Independent are left-leaning broadsheets. ${ }^{25}$ Articles were retrieved through the following search: 'jihadi bride* OR muhajirah OR muhajirat', and was restricted to articles published between 31 January 2013 and 31 January 2018, yielding 365 unique articles.

The articles were analyzed using the software program NVivo and were approached as follows: first, each article was open coded in order to draw out metaphorical expressions without the use of predefined categories. Metaphorical expressions are words or phrases used in ways that differ from their basic meanings, and as such the context, rather than the frequency, of particular expressions was of interest. For example, the word 'poison' as it related to the metaphor of toxicity (e.g. the 'poison' of jihadist ideology) was included in this analysis, while references to Team Poison (Junaid Hussain's I.S. computer hacking group) was not. The expressions derived from this initial indicative step were then searched (along with synonyms) within the rest of the articles. Expressions were included in the analysis if the sentence in question was about I.S. women or if it sought to explain the attractiveness of I.S. to these women. Finally, these metaphorical expressions were organized according to the central metaphors they invoked. Journalistic writing very often incudes words or phrases that are not used in the basic (dictionary defined) sense of their meaning, however, these are not considered to indicate metaphorical thinking unless a number of different expressions cluster around a particular metaphorical representation of the issue at hand. Table 1 illustrates the frequency of metaphorical expressions within these articles, along with the overarching metaphor each invoked. ${ }^{26}$ [Table 1 near here].

\section{Results}

Within news frame packages, metaphors serve to facilitate the comprehension of new situations through the establishment of similarity between a topic and a vehicle of 
thought. By using language that links a new phenomenon with an established idea, the strangeness of the phenomenon may be tamed and the sense of displacement it engenders brought back under control. This is important when considering the representation of the 'jihadi brides' and the novel challenge they represented. At one point something close to a moral panic emerged as women and girls were leaving the UK at a rate of one a week. Every newspaper studied here carried these stories as they unfolded, and metaphorical expressions served to domesticate a new and unknown phenomenon, restoring order through metaphors that placed this novel situation within the realm of the familiar.

The most frequent metaphorical expressions within the corpus were organized around three such metaphors, which represented the 'brides' as natural, biological and supernatural forces. As illustrated in Chart 1, all of the newspapers under study employed metaphorical expressions in their presentation of the women and girls in question, however, right-leaning tabloids employed these expressions, and therefore the metaphors they clustered around, considerably more frequently. This is unsurprising, given the well-established tendencies of such newspapers towards sensationalism and manufactured moral panic. ${ }^{27}$ Nevertheless, it should be noted that all of the newspapers studied here employed metaphorical expressions, regardless of their tabloid or broadsheet status and ideological leanings. [Chart 1 near here].

\section{Natural forces}

Metaphors of natural forces predominantly evoked water, representing each stage of these women's radicalization and migration, as well as I.S. more broadly, as streams, flows, waves, floods and surges. These expressions pointed to the overwhelming 'pull' of I.S., portraying the group as irresistible and the 'brides' as passive in their own radicalization, drawn along by the overpowering force of I.S. ideology. 
The Internet was broadly understood to be the starting point of radicalization, a place where young women were exposed to a "torrent of bile pouring forth every day from extremists," 28 while parents remained passively unaware of the "tide of hate and poison lapping into the bedrooms of susceptible young men and women." ${ }^{29}$ I.S. pulled towards it a "flood of extremists," $" 30$ creating a "surge in jihadist activity,"31 and young women were portrayed as swept along by this force. The three schoolgirls from Bethnal Green Academy (Amira Abase, Kadiza Sultana and Shamima Begum), who left the UK in February 2015, for example, were represented as "part of a flow of British youths to the war zone,"32 joining a "stream of young British Muslims,"33 and forcing police to escalate "efforts to stem the flow of prospective jihadis to Syria." 34

The unmanageable nature of the problem was further emphasized by reports that officials were "struggling to tackle a constant flow" $" 35$ of Britons to Syria and were "bracing themselves for an influx of jihadi brides," 36 where blocking re-entry was "the only way to prevent a new wave of deadly attacks." ${ }^{\text {,37 }}$ These metaphors served to represent I.S. as a body of water sweeping across the world like a tidal wave and carrying off young women as it passed. Such representations positioned the women as passive onlookers, rather than active subjects, in marked contrast to the way young British migrant men were portrayed (discussed below).

\section{Biological forces}

The unstoppable force of nature discussed above was also present in language that represented I.S.'s 'pull' for these women as a biological force, through expressions that evoked vegetation and disease. Following the terrorist attack on Manchester Arena in May 2017, the area of Moss Side (home to Salma and Zahra Halane, the so-called 'terror twins') was subject to scrutiny, and plant-related metaphors became frequent. representing Manchester was described as a place where the "evil seeds of hatred were 
sown in the suburbs," 38 and a "hotbed of extremism," ${ }^{39}$ where a "climate of division ha[d] been a fertile breeding ground for the recruiting sergeants of jihadism." 40 Multiculturalism was blamed for having "allowed a climate to grow in which extremist ideas ha[d] flourished within Britain's Muslim communities." 41 The "sharp rise in home-grown fanatics" ${ }^{42}$ meant the need to closely monitor Muslim private space as the site "where this [extremism] first germinates." ${ }^{43}$ Having been scattered, nurtured and grown, I.S.'s extremist ideas were believed to have put down roots in particular areas, implying both that they were well-established: "radical ideology appears to have taken root among some young city Muslims,"44 and unruly: "successive governments have failed to root out extremist ideology and disaffection among Muslims in the UK." ${ }^{45}$ A determined citizenry was thus required to locate and eradicate this threat.

These representations of radicalization as a biological force were reflected in epidemiological language that constructed I.S. as toxic. The group was said to be "poisoning vulnerable minds"46 and indoctrinating young people "with this hateful ideological poison, " 47 through "sectarian religiosity, sheer adventurism and cocksure, screw-you street swagger [which] have combined into a particularly heady and toxic alloy." 48 The toxicity of I.S. was contrasted with the former health of the women in question. The Bethnal Green girls, for example, were described as bright, popular and well-liked young women who "came from healthy homes," 49 and as I.S. was portrayed as a disease, ostensibly safe spaces were re-framed as places of infection. One article identified universities as serving to "incubate the virus of extremism" underground to "find a ready host in those who feel lost, alienated and resentful." 51 The risk of infection from I.S. extremism meant that even Mak Chishty of the Metropolitan Police warned fellow Muslim parents that "I am not immuni[z]ed. If I feel the need to be extra vigilant, then I think you need to feel the need to be extra vigilant." ${ }^{, 52}$ 


\section{The supernatural}

Alongside metaphors of unstoppable natural forces lurked more unnatural forces. These took two forms: one that represented I.S. itself as a supernatural force that bewitched the women and girls in question, and another that presented the 'brides' as monstrous.

I.S. was represented as other-worldly through metaphors that described Raqqa, I.S.'s makeshift capital, as the "HQ of evil"53 and "earth's closest vision of hell." ${ }^{54}$ I.S. fighters were described as "fiends," "horror movie ghouls" "56 and "manipulative monsters," $" 57$ taking part in a "ghoulish melodrama of hatred." hold on the women who travelled to Syria was also understood as other-worldly, transforming ordinary British women and girls into jihadists seemingly by magic. While Sally Jones was reportedly "under the spell of [Junaid] Hussain,"59 Joya Choudhury’s husband "mesmeri[z]ed her with his confidence," ${ }^{60}$ while Sharmeena Begum was said to have "fell under the spell of the Islamists;"61 and Aqsa Mahmood was described as "a woman entranced not just with the idea of Islamism but with joining Islamic State." ${ }^{\prime 2}$

The unearthly powers ascribed to jihadist men served to present the women in question as powerless, vulnerable and unable to resist their own enchantment. Any sympathy generated by these metaphors was displaced by the assertion that, once humans arrived in I.S. territory they were transformed into supernatural beings themselves. For example, JoJo Jones was said to be "gone forever, transformed beyond recognition by his evil mother [Sally],"63 and Aqsa Mahmood's parents were described, as "haunted and broken, devastated at the monster their child has turned into."64 This representation of Syria as a place that 'monsterized' served to place these women in a territory of supernatural forces. Bombed out citizens of Mosul were described as emerging "from the ground as dust covered spect[er]s into an earthly hell," ${ }^{65}$ Khadijah Dare's mother claimed that " "the devil' took her," 66 Tareena Shakil described her time 
in Syria as "a living nightmare...[that] ended up as hell"67 and Joya Choudhury stated that life in I.S. territory was like "living in a horror movie that wasn't ending." 68

\section{Discussion}

The results above return us to the research questions of this study: What does it mean to represent people as tides, toxins and monsters? What kind of actions do such representations make possible and what do they preclude?

The metaphors discussed here are not new, and metaphorical expressions of natural, biological and supernatural force have been identified in newspaper writing about immigration, extremism and conflict. However, their prevalence in articles that sought to explain the actions of the 'brides' is particularly interesting. What each of these have in common is the representation of I.S. as an unrelenting and overpowering force, and the young women in question as passive bystanders caught up in, or infected by, its unstoppable growth. It is important to note that, while some of these metaphorical expressions portrayed extremism more generally, their proliferation in articles that specifically sought to explain the actions of the 'jihadi brides' suggests that gendered explanations of politically violent women found expression in the metaphorical language used to represent them. These metaphors emphasized the passivity of the 'brides', explaining their radicalization as a result of exposure or enchantment, rather than their own active interest in jihad, and the women themselves as vulnerable and susceptible, but caught up in the irresistible force of movement towards I.S. territory, exposed to the ever-present virus of radicalization or spellbound. Beneath this representation of I.S. lies an understanding of the 'brides' as passive and vulnerable, perhaps even victims, but rarely as active participants in the I.S. project.

Such representations are not only gendered, they are also homogenizing, erasing diverse motivations for migrating to I.S. territory. The social media activity of the 
British 'brides' reveals a plurality of reasons for leaving the UK, including Aqsa Mahmood's desire to aid the victims of war, Khadijah Dare's dissatisfaction with the piety of British Muslim men and Tareena Shakil's attempt to ensure a place in heaven for herself and her family by migrating to the 'caliphate'. The media's tendency to use metaphors that treated the 'brides' as one entity did not allow for distinguishing motivations between those who sought to live in an Islamic state and those who wished to support the I.S. project. Instead, the metaphorical representation of the 'brides' embraced a depiction of young women as unwitting victims of IS propaganda, in marked contrast to the representation of male migrants, who were understood to be ideologically driven, active and committed to the jihadist cause. ${ }^{69}$

These representations of I.S. and the women involved as non-human forces also had a consistent and subtle dehumanizing effect. Water-based metaphors, that describe people as flows, surges, and waves are frequently found in reporting on immigration. ${ }^{70}$ Given the unprecedented numbers of people who left for I.S. territory, their depiction through water-based imagery may simply have been because journalists were drawing on long-established media frames of migration. Nevertheless, the connotations of this metaphor should be examined. As a mass noun, 'water' describes a homogenized, indistinct moving mass; in short, it portrays subjects devoid of individuality, ${ }^{71}$ and this has implications for the range of options available to manage the problem described. As Otto Santa Ana has put it:

\footnotetext{
The control of water varies from total mastery, such as when people shut off a kitchen faucet, to partial control, as in a hydroelectric dam. Great volume and movement of water imply greater need for safeguards and controls, and more powerful human agency to control the water... ${ }^{72}$
}

It is the sheer volume implied by the water metaphor that points to the need for greater 
human power to prevent an already dangerous situation getting further out of control.

Similar understandings may be detected in the metaphorical representation of I.S. migrants as biological forces, reducing them to a sub-human level and, again, drawing on historical constructions of outside 'others'. The dehumanizing of Jews as parasites and plants in fascist rhetoric is well-known, ${ }^{73}$ however, discourse in liberal democracies has frequently employed these metaphors in public speech about enemyothers. ${ }^{74}$ For example, immigration debates in early $20^{\text {th }}$ century America commonly represented immigrants as indigestible food, parasites or germs in the body of the nation. ${ }^{75}$ More recent work has pointed to the prevalence of these discourses in counterterrorism, including how metaphors of radicalization as a toxic and contagious disease in the UK have led to public health style counterterrorism responses ${ }^{76}$ and how the idea of the 'bad seed' has securitized Muslim communities in the U.S.. ${ }^{77}$ Both versions of the biological force metaphor point to particular ways of dealing with the problem at hand. The body politic can be inoculated against the virus, while the 'bad seeds' must be removed by a watchful horticulturalist. These actions, however, require the aid of a vigilant citizenry to keep a careful eye on developments.

Perhaps surprising about the biological force metaphor is the lack of metaphorical expressions that refer to animals. In their work on metaphors of the 'war on terror', Steuter and Wills noted the tendency to represent the wars in Afghanistan and Iraq through the metaphor of 'the hunt', through expressions such as 'lairs', 'nests' and 'swamps. ${ }^{78}$ It is notable that such language was occasionally present, but was not significant within the articles examined here. It is possible that journalists may have purposely avoided animal metaphors, given their link with the dehumanization of the Nazi and Stalinist regimes. ${ }^{79}$ Alternatively, the relative infrequency of these metaphors may be due to the fact that the articles studied here were retrieved specifically through 
search terms designed to capture writing on women. Since these metaphors tend to be employed to describe combatants, women are perhaps less likely to be portrayed through such terms. Comparative research would enable greater insight into whether the lack of animal-related metaphors was due to sampling issues or can tell us more about the specific media construction of I.S.

While the metaphors of natural and biological force are well established in newspaper writing on immigration, supernatural metaphors tend to emerge in relation to conflict. Richard Devetak has how enemies are frequently represented as supernatural beings in international relations, highlighting the portrayals of Al Qaeda as invisible and ghostly, but nevertheless possessing unlimited destructive power. ${ }^{80}$ Particularly important here is the idea of 'evil', the most frequently occurring metaphorical expression in the articles. The rhetoric of 'evil' in conflict situations has been investigated by a number of scholars, particularly in relation to the 'war on terror', and its repeated construction as a war of 'good versus evil. ${ }^{81}$ The criminological literature on women offenders has also noted this as a key signifier, and has highlighted the tendency to portray female deviance as 'evil' through gendered discourses that 'monsterize', constructing women criminals as outside both the moral and social orders. ${ }^{82}$ The threat that deviant criminal women represent to the social order may be seen to be reflected in the threat that I.S. women were understood to pose to the countries they departed. The presence of British women in Syria was not considered a security threat in the same way as that posed by their male co-nationals. In fact, arguably, the threat posed by the 'brides' was more profound. Their rejection of the security, stability and gender-based freedoms of their lives in the UK was deeply disturbing to established civilizational narratives of 'West is best', and this may explain 
the tendency to metaphorically represent them as succumbing to (and often becoming) supernatural forces, against which they were powerless.

\section{The consequences of framings}

Metaphors work to frame an unfamiliar phenomenon, making it comprehensible by appealing to familiar experiences. However, they also serve a further purpose. By mapping the conceptual knowledge of one domain on to another, they imply not only how the subject in question should be evaluated, but also how it should be managed.

A number of empirical studies have demonstrated that metaphorical framing influences people's perceptions of how best to manage problems. ${ }^{83}$ Spencer, for example, has argued that representations of the 'barbaric terrorist' implied the tightening of borders to keep out the foreign 'other', while the discourse of 'evil' pointed to more severe action, relying on the perception that engagement was impossible. ${ }^{84}$ Studies measuring the effects of metaphorical representation have similarly found that proposed solutions are influenced by these framings. One study presented two groups with an identical fictional crime report, changing only the way crime was metaphorically represented, and found that those presented with the "crime as a virus' metaphor were more likely to recommend public health style social reforms, while those presented with the 'crime as a wild beast' metaphor favored heavier policing and more militant tactics. ${ }^{85}$ Perhaps more importantly, the likelihood of choosing one set of actions over another remained the same even when participants did not even notice the metaphor in question, suggesting that metaphorical representations influence mental models even when we do not perceive that they are present.

The constructivist position highlights the influence that representations have on policy from a post-positivist perspective, where the question of concern is not why a 
particular action happened, but how that action became possible. ${ }^{86}$ That high-level government figures were adopting some of the metaphors described here is well illustrated by prime minister David Cameron's speech on extremism in November 2015:

When you are dealing with radicali[z]ed European Muslims, linked to ISIL in Syria and inspired by a poisonous narrative of extremism, you need an approach that covers the full spectrum - military power, counter-terrorism expertise and defeating the poisonous narrative that is the root cause of this evil... The root cause of this threat is the poisonous ideology of extremism itself. This ideology, this diseased view of the world, has become an epidemic - infecting minds from the mosques of Mogadishu to the bedrooms of Birmingham. And we have to stop it at the start - stop this seed of hatred even being planted in people's minds, let alone allowing it to grow. ${ }^{87}$

The extent to which such frames influenced the acceptability of particular actions is difficult to assess, but the prime minister's use of metaphorical language to explain the pull of I.S. is important given that none of these metaphors pointed to the possibility of rehabilitation. Natural and supernatural forces cannot be engaged with, and furthermore, they are dangerous.

Shortly after Cameron's speech, the ambiguous status of the 'brides' was illustrated by then-defence secretary, Michael Fallon, who was evasive when asked by the Joint Committee on Human Rights in what circumstances drone strikes were approved and whether there existed a 'third category' between target and innocent civilians:

The Chair [Harriet Harman MP]: So you are saying there is a third category. There is the target; there are innocent civilians; and then there is a third category, which is not the target but not innocent civilians either, and therefore in pursuing a target it is all right for people in that category to be killed...? If somebody is involved in ISIL - because they are driving a tanker of oil that is going to be used by ISIL, or they are working in an oilfield, or they are what is described as a jihadi bride-are they in this third category; that is, not a target but not an innocent civilian either? 
Michael Fallon MP: ... we would look at this on a case-by-case basis, look at the numbers of other people involved, and apply the tests of proportionality and military advantage. Does the advantage of stopping potentially large loss of life on our own streets outweigh the necessity of one or two further casualties? What is proportionate in each case is a matter for the consideration of each case. ${ }^{88}$

The increasing ambiguity over the status of the 'brides' is important. The Additional Protocols of the Geneva Convention protect civilians against attack unless they take a direct part in hostilities. This means that those taking an indirect part, even if they are sustaining the war effort through propaganda and recruitment, may not be legitimately targeted under international humanitarian law. ${ }^{89}$ However, in the case of the jihadi brides', possibilities for action shifted over a short period of time. In late 2014, policy to deal with those who had migrated to Syria involved refusing them entry back to the UK. By summer 2017 Government ministers were openly supporting the targeted killing of British women. Fallon's replacement as defense secretary, Gavin Williamson, unreservedly supported the drone campaign, arguing "a dead terrorist can't cause any harm to Britain," 90 a sentiment shared by Minister for International Development, Rory Stewart, who, a few days after Jones's death was reported, stated:

They are absolutely dedicated, as members of the Islamic State, towards the creation of a caliphate. They believe in an extremely hateful doctrine which involves killing themselves, killing others and trying to use violence and brutality to create an 8th Century, or 7th Century, state. So I'm afraid we have to be serious about the fact these people are a serious danger to us, and unfortunately, the only way of dealing with them will be, in almost every case, to kill them. ${ }^{91}$

This more hardline attitude to British I.S. members has continued at the highest level of government. In July 2018, home secretary Sajid Javid took the unprecedented decision to extradite the remaining members of the British 'Beatles' I.S. cell without 
seeking assurances that they would not face the death penalty. Although this effort was suspended following a legal challenge, the dispensation of the decades old 'death penalty assurance' suggests a shift in position, if not policy, towards those associated with I.S. A similar disregard has been shown for those Britons who number among the estimated 2000 and 1400 women and children respectively held in Kurdish and Iraqi detention, despite the concerns of human rights groups that Baghdad courts were sentencing foreign women to death for non-violent crimes. ${ }^{92}$ Government ambivalence to the fate of British 'jihadi brides' was further demonstrated in February 2019 when one of the Bethnal Green schoolgirls, Shamima Begum, was located in Kurdish detention, heavily pregnant and wishing to return to the UK for the sake of her child, having lost two infants that year to malnutrition and illness. At the time of her disappearance, Metropolitan Police assistant commissioner, Mark Rowley, had given assurances that the girls would not be treated as terrorists should they return. However, four years later Javid revoked Begum's British passport in a move that, in contravention of international law, effectively rendered her stateless. ${ }^{93}$

How these actions became possible is of crucial concern, and metaphors are one component of a discourse that constructs reality in a particular way, enabling certain actions to follow relatively uncomplicatedly, while others become increasingly unthinkable.

This article opened with a discussion of the case of Sally Jones, asking what changed in the two years between her husband's assassination and her own to make a previously unacceptable action possible. Although many variables may have impacted on the decision to target Jones despite the presence of her son, ${ }^{94}$ the social construction of the 'jihadi brides' was an important contributor to this shift in possibilities. The argument of this paper is not that the consistent dehumanization within these 
metaphorical representations directly led to drone strikes, or even indifference to the complex moral questions raised by them. What is going on is much subtler: dehumanization does not lead to particular policy options, in the sense that particular metaphors cause certain policies. Rather, discourses that dehumanize subjects make certain options more, or less, appropriate. It is this narrowing of possibilities that makes particular policies feasible.

The drone strike that killed Sally Jones and her son was made possible partly through the discursive construction of what the 'jihadi brides' were, the threat they posed and the actions deemed necessary to deal with them. These representational forces were starkly demonstrated in the aftermath of Jones's killing and the newspaper discourse that dominated. The ethical and legal quandaries thrown up by the child's death were smoothed over by a visual and textual rendering of Jojo as deserving of his fate. As Major General Chip Chapman, the Ministry of Defence's former head of counterterrorism, stated: "This 12 -year-old had brutally murdered people. He is not someone we should necessarily empathize with. I think one could make a case that he could be a legitimate target." 95 These sentiments were indirectly legitimized by the widespread publication of images from an I.S. propaganda video of the smiling child holding a gun to the head of a Kurdish prisoner. The subtext was hardly subtle; the boy had murdered, and therefore his death was not 'collateral damage,' but a necessary, and even legitimate, action. Whether empathy with Jojo was possible was tied to the fact that he was a child, who had been taken to Syria by his mother, ideologically conditioned by I.S. and compelled to execute prisoners. His culpability in such circumstances, and the legitimacy of his targeting (even if indirect), was problematic at best, but the representations of I.S. in general, and the 'brides' in particular, as new 
threats that required drastic new responses facilitated media acceptance that the threat from his mother could only be neutralized if her child was sacrificed at the same time.

\section{Conclusion}

When the 'jihadi brides' first came to widespread public attention in summer 2014, the notion that British women and girls would choose to decamp to a war-torn country ruled by gender segregation was represented as utterly inexplicable, and newspaper discourse sought to frame the issue in order to explain this novel phenomenon to an unprepared public. Metaphors were an important element of this frame package, serving to reduce complexity by linking this new reality with established ideas and thus rendering the 'brides' comprehensible. Far from being singular instances of elaborate journalistic language, these metaphorical expressions pointed toward particular cognitive understandings of the women in question, clustering around three recurring metaphors that represented I.S. as a natural, biological and supernatural force, and the 'brides' as inextricably and uncontrollably caught up in them.

The frequency of these metaphors in writing on women suggests that, in attempting to explain the 'brides', reporters regurgitated well-established tropes of politically violent women as naïve, vulnerable victims, devoid of the ideological commitment assumed of male migrants, at least prior to their arrival in I.S. territory. Such representations effectively homogenized the category of the 'brides', erasing their agency, neglecting their stated motivations and serving both to collectively dehumanize them and legitimize their annihilation.

By taking seriously constructivism's claim that discursive choices about the representation of a phenomenon influences the possibilities for its management, the analysis presented here has stressed the importance of studying metaphorical frames in media discourse and considering their consequences. All discursive research is subject 
to limitations, particularly when undertaken by an individual researcher without the internal coding validity checks that a team of researchers can provide. I have attempted to mitigate these limitations by employing an inductive approach, drawing metaphorical expressions from the data, sorting them into the overarching metaphors they invoked and testing the validity of these categories with reference to the rich literature on media metaphor usage.

While any constructivist approach must be wary of over-claiming, a deeper appreciation of how media framing may contribute to a broadening or narrowing of policy options is an important addition to our understanding of the changing approach towards women who departed, and often now seek to return, to their home countries. This article has presented an analysis of how representations make space for the development of new norms, but it also suggests fruitful areas for future research. Most obviously, case studies, or comparative analyses, of individual women would generate important longitudinal data on the relationship between their metaphorical representation and the actions deemed suitable to deal with them. Such an approach is beyond the scope of this paper, but would allow more fine-grained analysis of whether and how metaphors changed over time and if policy approaches changed in parallel.

The fall of the 'caliphate' has created profound dilemmas for those states which must now contend with the problem of returnees. Not only does the lack of evidence of activities in Syria make prosecution of women migrants particularly difficult, but the status of children taken to or born in I.S. territory is uncertain, and the costs associated with monitoring and treating these, often traumatized, families may be difficult to bear for governments whose populations are hostile to their reabsorption. In the wake of these new realities, there is evidence that new norms appear to be developing with 
regard to the conceptualization and treatment of both I.S. fighters and their families, made possible in part by the novel social constructions of the subjects in question.

The effects of such social constructions can never be definitively discerned, given the complexity of variables that influence policy choices. However, discourses that dehumanize must not be dismissed. The high profile 'brides' that became the central focus of media attention in fact made up a very small percentage of those known to have left. The vast majority of those who migrated maintained low profiles, neither recruiting to the 'caliphate' nor glorifying terrorism. The label 'jihadi brides', however, collected around it representations that served to flatten the women and girls constructed thus, rendering their motivations and activities uniformly diabolical and reducing the 'brides' into a 'third category' - neither targets nor innocent civilians, but individuals whose lives were more disposable because of their decision to migrate. Homogenized and dehumanized, the 'brides' found little sympathy from the majority of these newspapers, and military action aimed at their deliberate or 'collateral' eradication found few critics.

${ }^{1}$ Carolyn Hoyle, Alexandra Bradford, and Ross Frenett, Becoming Mulan? Female Western Migrants to ISIS (Institute for Strategic Dialogue, 2015); Marion Van San, "Belgian and Dutch Young Men and Women Who Joined ISIS: Ethnographic Research among the Families They Left behind," Studies in Conflict and Terrorism 41, no. 1 (2018): 39-58; Maren Hald Bjørgum, "Jihadi Brides: Why Do Western Muslim Girls Join ISIS?," Global Politics Review 2, no. 2 (2016): 91-102; Erin Marie Saltman and Melanie Smith, “Till Martyrdom Do Us Part": Gender and the ISIS Phenomenon (Institute for Strategic Dialogue, 2015), https://icsr.info/2015/06/02/icsr-report-till-martyrdom-us-part-genderisis-phenomenon/; Clara Isabel Morgades-Bamba, Patrick Raynal, and Henri Chabrol, "Exploring the Radicalization Process in Young Women," Terrorism and Political Violence, 2018, 1-19, https://doi.org/10.1080/09546553.2018; Leah Windsor, "The Language of Radicalization: Female Internet Recruitment to Participation in ISIS 
Activities," Terrorism and Political Violence Online (2018): 1-33,

https://doi.org/10.1080/09546553.2017.1385457; Emily Winterbotham and Elizabeth

Pearson, "Different Cities, Shared Stories: A Five-Country Study Challenging

Assumptions around Muslim Women and CVE Interventions," RUSI Journal 161, no. 5

(2016): 54-65; Anita Peresin and Alberto Cervone, "The Western Muhajirat of ISIS,"

Studies in Conflict \& Terrorism 38, no. 7 (2015): 495-509; Anita Perešin, "Fatal

Attraction: Western Muslims and ISIS," Perspectives on Terrorism 9, no. 3 (2015): 21-38.

2 J Musial, “'My Muslim Sister , Indeed You Are a Mujahidah' - Narratives in the Propaganda of the Islamic State to Address and Radicalize Western Women. An Exemplary Analysis of the Online Magazine Dabiq," Journal for Deradicalization 9 (2016): 39-100; Suhartini Samsudin and Anitawati Mohd Lokman, "Women and the Themes and Narratives of the 'Diary of a Muhajirah' Tumblr Page," Joural of Media and Informaton Warfare 8, no. June (2016): 117-55.

${ }^{3}$ Caroline Picart, “'Jihad Cool/Jihad Chic': The Roles of the Internet and Imagined Relations in the Self-Radicalization of Colleen LaRose (Jihad Jane)," Societies 5, no. 2 (2015): 35483; Laura Huey and Eric Witmer, "\#IS_Fangirl: Exploring a New Role for Women in Terrorism," Journal of Terrorism Research 7, no. 1 (2016): 1-10.

${ }^{4}$ Jytte Klausen, "Tweeting the Jihad: Social Media Networks of Western Foreign Fighters in Syria and Iraq," Studies in Conflict and Terrorism 38, no. 1 (2015): 1-22.

${ }^{5}$ D. Chatterjee, "Gendering ISIS and Mapping the Role of Women," Contemporary Review of the Middle East 3, no. 2 (2016): 201-18; Marta Kollarova, "Good or Bad Agents? Western Fascination with Women and the Construction of Female Objects during the ISIS/ISIL Crisis," in Gendering War and Peace Reporting, ed. Berit von der Lippe and Rune Ottosen (Gothenburg: Nordicom, 2016), 143-58; Nava Nuraniyah, "Not Just Brainwashed: Understanding the Radicalization of Indonesian Female Supporters of the Islamic State," Terrorism and Political Violence 30, no. 6 (2018): 890-910.

${ }^{6}$ Rainer Hülsse and Alexander Spencer, "The Metaphor of Terror: Terrorism Studies and the Constructivist Turn," Security Dialogue 39, no. 6 (2008): 571-92.

${ }^{7}$ Richard Jackson, Writing the War on Terrorism: Language, Politics and Counter-Terrorism (Manchester: Manchester University Press, 2005); Jacob L. Stump and Priya Dixit, “Toward a Completely Constructivist Critical Terrorism Studies," International Relations 26, no. 2 (2012): 199-217; Alexander Spencer, "The Social Construction of Terrorism: Media, Metaphors and Policy Implications," Journal of International Relations and Development 15, no. 3 (2012): 393-419.

${ }^{8}$ Amit Lavie-Dinur, Yuval Karniel, and Tal Azran, “'Bad Girls': The Use of Gendered Media Frames in the Israeli Media's Coverage of Israeli Female Political Criminals," Journal of Gender Studies 24, no. 3 (2015): 326-46; Brigitte L. Nacos, "The Portrayal of Female 
Terrorists in the Media: Similar Framing Patterns in the News Coverage of Women in Politics and in Terrorism," Studies in Conflict and Terrorism 28, no. 5 (2005): 435-51. ${ }_{9}^{9}$ Anne-Marie McManus, "Sentimental Terror Narratives: Gendering Violence, Dividing Sympathy," Journal of Middle East Women's Studies 9, no. 2 (2013): 80-107; Claudia Brunner, "Female Suicide Bombers - Male Suicide Bombing? Looking for Gender in Reporting the Suicide Bombings of the Israeli-Palestinian Conflict," Global Society 19, no. 1 (2005): 29-48.

${ }^{10}$ Lavie-Dinur, Karniel, and Azran, “'Bad Girls': The Use of Gendered Media Frames in the Israeli Media's Coverage of Israeli Female Political Criminals"; Tern Toles Patkin, "Explosive Baggage: Female Palestinian Suicide Bombers and the Rhetoric of Emotion.," Women \& Language 27, no. 2 (2004): 79-88.

${ }^{11}$ Chatterjee, "Gendering ISIS and Mapping the Role of Women"; Kollarova, "Good or Bad Agents? Western Fascination with Women and the Construction of Female Objects during the ISIS/ISIL Crisis”; Alice Martini, "Making Women Terrorists into 'Jihadi Brides': An Analysis of Media Narratives on Women Joining ISIS," Critical Studies on Terrorism 11, no. 3 (2018): 458-77; Shiva Zarabadi and Jessica Ringrose, "The Affective Birth of 'Jihadi Bride' as New Risky Sexualized 'Other': Muslim Schoolgirls and Media Panic in an Age of Counter-Terrorism," in Youth Sexualities: Public Feelings and Contemporary Cultural Politics, 2018, 83-106; Y. Ibrahim, "Visuality and the 'Jihadi-Bride' the ReFashioning of Desire in the Digital Age," Social Identities 25, no. 2 (2019): 186-206.

${ }^{12}$ Martini, “Making Women Terrorists into 'Jihadi Brides': An Analysis of Media Narratives on Women Joining ISIS.”

${ }^{13}$ For example, in November 2018 The Sun was the UK's most popular (paid) newspaper, with a circulation of 1.4 million. The Daily Mail and the Daily Mirror came $2^{\text {nd }}$ and $6^{\text {th }}$ with circulation figures of 1.2 and 0.5 million respectively. By contrast, the most widely circulated daily broadsheet was The Times, at 0.42 million. Freddy Mayhew, "National Newspaper and Online ABCs: Web Figures in Double-Digit Drop as Print Circulation Falls across the Board," Press Gazette, 2018, https://www.pressgazette.co.uk/nationalnewspaper-online-abcs-web-figures-in-double-digit-drop-as-print-circulation-falls-acrossthe-board/.

${ }^{14}$ Alexander Spencer, The Tabloid Terrorist: The Predicative Construction of New Terrorism in the Media (Houndmills: Palgrave Macmillan, 2010), 1.

${ }^{15}$ Nuraniyah, "Not Just Brainwashed: Understanding the Radicalization of Indonesian Female Supporters of the Islamic State," 893.

${ }^{16}$ Robert M. Entman, "Framing: Toward Clarification of a Fractured Paradigm," Journal of Communication 43, no. 4 (1993): 52. 
${ }^{17}$ Pippa Norris, Montague Kern, and Marion Just, "Framing Terrorism," in Framing Terrorism: The News Media, the Government and the Public, ed. Pippa Norris, Montague Kern, and Marion Just (Routledge, 2003), 3-23; Entman, "Framing: Toward Clarification of a Fractured Paradigm.”

${ }^{18}$ Keith L Shimko, "Metaphors and Foreign Policy Decision Making," Political Psychology 15, no. 4 (1994): 655-71.

${ }^{19}$ George Lakoff and Mark Johnson, Metaphors We Live By (Chicago: University of Chicago Press, 1980), 3-4.

${ }^{20}$ Hank Johnston, “A Methodology for Frame Analysis: From Discourse to Cognitive Schemata," in Social Movements and Culture: Social Movements Protest and Contention, ed. Hank Johnston and Bert Klandermans (Minneaopolis: University of Minnesota Press, 1995), 217-46.

${ }^{21}$ Shimko, "Metaphors and Foreign Policy Decision Making," 661.

${ }^{22}$ Ofcom, "News Consumption in the UK: 2018," 2018, https://www.ofcom.org.uk/_data/assets/pdf_file/0024/116529/news-consumption2018.pdf.

${ }^{23}$ James N. Druckman and Kjersten R. Nelson, "Framing and Deliberation: How Citizen Conversation Limits Elite Influence," American Journal of Political Science 47, no. 4 (2003): 729-45; Paul R. Brewer and Kimberly Gross, "Values, Framing, and Citizens' Thoughts about Policy Issues: Effects on Content and Quantity," Political Psychology 26, no. 6 (2005): 929-48; James N Druckman, “On the Limits of Framing Effects: Who Can Frame?," The Journal of Politics 63, no. 4 (2001): 1041-66.

${ }^{24}$ Dietram A. Scheufele, "Framing as a Theory of Media Effects," Journal of Communication Winter (1999): 103-22.

${ }^{25}$ The Independent moved to a digital-only platform in April 2016. Only printed (rather than online) articles were retrieved for this study.

${ }^{26}$ Two other metaphors, relating to animals (flock (5), crawl (2), cage (1)) and the metaphor of hunting (hunt (10), prey (6)), appeared less frequently and are not analyzed here due to space limitations.

${ }^{27}$ See, for example: Julian Matthews and Andy R. Brown, "Negatively Shaping the Asylum Agenda? The Representational Strategy and Impact of a Tabloid News Campaign," Journalism 13, no. 6 (2012): 802-17.;

28 "Web giants turning a blind eye to terror," Daily Mail, August 25, 2015, p. 16. (Unless otherwise indicated, all emphases are my own).

${ }^{29}$ Graham Grant. "Web giants must pay the price for spreading death cult propaganda," Daily Mail, June 6 2017, p. 18. 
${ }^{30}$ Chris Greenwood, Larisa Brown \& Inderdeep Bains. "Three UK Boys Seized on Way to Syria," Daily Mail, March 16, 2015, p. 8.

${ }^{31}$ Sean O'Neill. “£24 Million to Help Stop Jihadis Travelling to Syria,” The Times, March 19, 2015, p. 13.

${ }^{32}$ Georgie Keate \& Fiona Hamilton. "Terror suspect 'was carrying false passport"” The Times, March 19, 2015, p. 23.

${ }^{33}$ Nick Parker. "Turkey holds 9 Brits on way to join jihad," The Sun, April 2, 2015, p. 6.

34 “Target: Teenagers" Daily Mail, March 12, 2015, p. 10.

${ }^{35}$ Chris Greenwood. "2,000 fighters from UK?” Daily Mail, April 3, 2015, p. 5.

${ }^{36}$ George Odling. "British 'IS Bride' Bailed After Flying to UK with Baby". Daily Mail, January 22, 2018, p. 25.

${ }^{37}$ Gavin Madeley. "Banned from UK... the Scots schoolgirl who ran off to join ISIS," Daily Mail, August 7, 2017, p. 6.

${ }^{38}$ Sue Reid. "How city became crucible of extremism," Daily Mail, May 24, 2017, p. 15.

${ }^{39}$ Martin Phillips. "Fanatics Suburbia," The Sun, May 25, 2017, p. 14.

${ }^{40}$ Manzoor Moghal. "We Muslims MUST stop Blaming Others for the Way Our Young Are Radicalised," Daily Mail, June 17, 2015, p. 16.

${ }^{41}$ Trevor Phillips. "This Life and Death Struggle," Daily Mail, April 11, 2016, p. 12.

${ }^{42}$ Tom Whitehead. "Women lured to Isil take UK terror arrests to record high," Daily Telegraph, September 11, 2015, p. 8.

${ }^{43}$ Larisa Brown. "Brainwashed Muslim children aged 5 think Christmas is banned," Daily Mail, May 25, 2015, p. 20.

${ }^{44}$ Phillips. "Fanatics Suburbia," p. 14.

${ }^{45}$ Ian Drury. "1 in 4 UK Muslims are sympathetic to the Hebdo killers," Daily Mail, February 26, 2015, p. 8.

46 "Web giants turning a blind eye to terror," Daily Mail, p. 16.

${ }^{47}$ Arthur Martin, Jim Norton \& Ian Drury. "Now jihadi bride school is centre of terror probe," Daily Mail, March 30, 2015, p. 8.

${ }^{48}$ Boyd Tonkin. 'They're flippant, fanatical... and distinctly British," Independent, August 23, 2014 , p. 35.

${ }^{49}$ Will Pavia. "I would have gone to Syria. My parents laid the foundation" The Times, March 26, 2015 , p. 4.

${ }^{50}$ Jonathan Dimbleby. "For freedom of speech, these are troubling times," The Guardian, September 21, 2015, p. 29.

${ }^{51}$ Dimbleby. "For freedom of speech, these are troubling times," p. 29.

${ }^{52}$ Brown. "Brainwashed Muslim children aged 5 think Christmas is banned," p. 20.

${ }^{53}$ Tom Morgan \& Paul Sims. "Angels are on way to HQ of Evil," The Sun, June 18, 2015, p. 4. 
${ }^{54}$ Grace Dent. "Do girls who plot to join Isis really miss their teddy bears?" Independent, February 24, 2015, p. 21.

55 “Fiends Seized Twins' Mum," The Sun, November 3, 2014, p. 11.

${ }^{56}$ Dent. "Do girls who plot to join Isis really miss their teddy bears?" p. 21.

${ }^{57}$ Alex Preston. "It's up to us to stop these Muslim girls making the worst mistake of their lives," The Guardian, November 10, 2015, p. 31.

${ }^{58}$ Tonkin. "They're flippant, fanatical... and distinctly British," p. 35

${ }^{59}$ Sue Reid. "Ex-punk rocker who turned her little boy into an IS fanatic," Daily Mail, October 13, 2017, p. 15.

${ }^{60}$ Barbara Davies. "Has the British beauty who fled her ISIS husband REALLY cut all ties with him?" Daily Mail, January 14, 2017, p. 38.

${ }^{61}$ Emine Sinmaz, Sue Reid \& Sam Marsden. "She loved Rihanna, clothes and make-up. Then she fell under spell of Islamists," Daily Mail, March 14, 2015, p. 4.

${ }^{62}$ Emma Cowing. "From a private school to terror in Syria," Daily Mail, September 6, 2014, p. 10.

${ }^{63}$ Barbara Davies. "How his twisted mother turned Joe, 11, into a grinning ISIS killer," Daily Mail, September 3, 2016, p. 24.

64 "Insidious threat to precious children," Daily Mail, February 13, 2016, p. 19.

${ }^{65}$ Anthony Loyd. "The street in which the caliphate died," The Times, July 15, 2017, p. 16.

${ }^{66}$ Gordon Rayner \& Gregory Walter. "Boy they call Jihadi Junior is my grandson," Daily Telegraph, January 5, 2016, p. 4.

${ }^{67}$ Dan Sales. "My Hell in I.S. Base," The Sun, January 17, 2015, p. 8.

${ }^{68}$ Davies. "Has the British beauty who fled her ISIS husband REALLY cut all ties with him?" p. 38 .

${ }^{69}$ To fully explore how these differences were metaphorically represented it would be necessary to undertaken a comparative analysis of reporting of male versus female migrants. However, even a cursory glance at the media construction of male foreign fighters demonstrates that their agency was assumed through active verbs (e.g. Ensor, J. "Jihadi John hid in lorry to leave UK and join Isil fighters in Syria." Daily Telegraph, April 28, 2015 , p. 6), while women were much problematically understood as victims through passive sentence construction (e.g.: West, A. "Groomed to be a jihadi bride.” The Sun, October 1, 2014, p. 4).

${ }^{70}$ Andreas Musolff, "Dehumanizing Metaphors in UK Immigrant Debates in Press and Online Media," Journal of Language Aggression and Conflict 3, no. 1 (2015): 41-56; Jonathan Charteris-Black, "Britain as a Container: Immigration Metaphors in the 2005 Election Campaign," Discourse and Society 17, no. 5 (2006): 563-81. 
${ }^{71}$ Christopher Hart, "Moving beyond Metaphor in the Cognitive Linguistic Approach to CDA: Construal Operations in Immigration Discourse," in Critical Discourse Studies in Context and Cognition, ed. Christopher Hart (Amsterdam: John Benjamins Publishing Company, 2011), 171-92.

${ }^{72}$ Otto Santa Ana, Brown Tide Rising: Metaphors of Latinos in Contemporary American Public Discourse (Austin: University of Texas Press, 2002), 75.

${ }^{73}$ Andreas Musolff, "What Role Do Metaphors Play in Racial Prejudice? The Function of Antisemitic Imagery in Hitler's Mein Kampf," Patterns of Prejudice 41, no. 1 (2007): 2143; Andreas Musolff, Metaphor, Nation, and the Holocaust: The Concept of the Body Politic (New York; London: Routledge, 2010).

${ }^{74}$ Edmund P Russell, “'Speaking of Annihilation': Mobilizing for War against Human and Insect Enemies, 1914-1945," The Journal of American History 82, no. 4 (1996): 1505-29.

${ }^{75}$ See also: Charteris-Black, "Britain as a Container: Immigration Metaphors in the 2005 Election Campaign"; David Cisneros, "Contaminated Communities: The Metaphor of 'Immigrant as Pollutant' in Media Representations of Immigration," Rhetoric \& Public Affairs 11, no. 4 (2008): 569-601; Musolff, "Dehumanizing Metaphors in UK Immigrant Debates in Press and Online Media."

${ }^{76}$ Charlotte Heath-Kelly, "The Geography of Pre-Criminal Space: Epidemiological Imaginations of Radicalisation Risk in the UK Prevent Strategy, 2007-2017,” Critical Studies on Terrorism 10, no. 2 (2017): 297-319; Charlotte Heath-Kelly, “Algorithmic Autoimmunity in the NHS: Radicalisation and the Clinic," Security Dialogue 48, no. 1 (2017): 29-45.

${ }^{77}$ Clara Eroukhmanoff, "The Remote Securitisation of Islam in the US Post-9/11: Euphemisation, Metaphors and the 'logic of Expected Consequences' in CounterRadicalisation Discourse," Critical Studies on Terrorism 8, no. 2 (2015): 246-65.

${ }^{78}$ Erin Steuter and Deborah Wills, “'The Vermin Have Struck Again': Dehumanizing the Enemy in Post 9/11 Media Representations," Media, War \& Conflict 3, no. 2 (July 12, 2010): 152-67; Erin Steuter and Deborah Wills, "Discourses of Dehumanization: Enemy Construction and Canadian Media Complicity in the Framing of the War on Terror," Global Media Journal 2, no. 2 (2009): 7-24.

${ }^{79}$ Musolff, "Dehumanizing Metaphors in UK Immigrant Debates in Press and Online Media," 51.

${ }^{80}$ Richard Devetak, "The Gothic Scene of International Relations: Ghosts, Monsters, Terror and the Sublime after September 11," Review of International Studies 31, no. 4 (2005): 637.

${ }^{81}$ Aditi Bhatia, "Religious Metaphor in the Discourse of Illusion: George W. Bush and Osama Bin Laden,” World Englishes 26, no. 4 (2007): 507-24; Robert L. Ivie and Oscar Giner, "Hunting the Devil: Democracy's Rhetorical Impulse to War," Presidential Studies 
Quarterly 37, no. 4 (2007): 580-98; Annita Lazar and Michelle M. Lazar, “The Discourse of the New World Order: 'Out-Casting'the Double Face of Threat," Discourse \& Society 15, no. 2-3 (2004): 223-42.

${ }^{82}$ Eileen Berrington and Päivi Honkatukia, “An Evil Monster and a Poor Thing: Female Violence in the Media," Journal of Scandinavian Studies in Criminology and Crime Prevention 3, no. 1 (2002): 50-72; Siobhan Weare, “'The Mad', 'The Bad', 'The Victim': Gendered Constructions of Women Who Kill within the Criminal Justice System," Laws 2, no. 3 (2013): 337-61.

${ }^{83}$ Stephen M. Utych, "How Dehumanization Influences Attitudes toward Immigrants," Political Research Quarterly 71, no. 2 (2018): 440-52; Mark J. Landau and Lucas A. Keefer, "This Is like That: Metaphors in Public Discourse Shape Attitudes," Social and Personality Psychology Compass 8, no. 8 (2014): 463-73; Paul H. Thibodeau and Stephen J. Flusberg, "Metaphorical Accounting: How Framing the Federal Budget Like a Household's Affects Voting Intentions," Cognitive Science 41 (2017): 1168-82; Lucas A. Keefer et al., “Exploring Metaphor's Epistemic Function: Uncertainty Moderates Metaphor-Consistent Priming Effects on Social Perceptions," Journal of Experimental Social Psychology 47, no. 3 (2011): 657-60.

${ }^{84}$ Spencer, "The Social Construction of Terrorism: Media, Metaphors and Policy Implications," 410.

${ }^{85}$ Paul H. Thibodeau and Lera Boroditsky, "Metaphors We Think with: The Role of Metaphor in Reasoning," PLOS ONE 6, no. 2 (2011), https://doi.org/10.1371/journal.pone.0016782. For critique, see: J. Steen, Gerard, E. Gudrun Reijnierse, and Christian Burgers, "When Do Natural Language Metaphors Influence Reasoning? A Follow-Up Study to Thibodeau and Boroditsky (2013)," PLoS ONE 9, no. 12 (2014), https://journals.plos.org/plosone/article?id=10.1371/journal.pone.0113536.

${ }^{86}$ Roxanne Lynn Doty, "Foreign Policy as Social Construction: A Post-Positivist Analysis of U.S. Counterinsurgency Policy in the Philippines," International Studies Quaterly 37, no. 3 (1993): 297-320.

${ }^{87}$ David Cameron, “Lord Mayor's Banquet 2015: Prime Minister's Speech,” Gov.UK, November 16 2015, accessed May 31, 2019, https://www.gov.uk/government/speeches/lord-mayors-banquet-2015-prime-ministersspeech. A survey of 181 speeches, press conferences and statements retrieved from The Prime Minister's Office on gov.uk website using the search terms 'daesh' and 'ISIL', and covering both David Cameron and Theresa May's time in office, revealed that while metaphors of natural disaster did not appear at all, biological and supernatural metaphors were frequently used by the prime minister to construct the I.S. threat. 
${ }^{88}$ Joint Committee on Human Rights “The UK Government's Policy on the Use of Drones for Targeted Killing, HC 574" House of Commons, December 16, 2015.

http://data.parliament.uk/writtenevidence/committeeevidence.svc/evidencedocument/huma n-rights-committee/the-uk-governments-policy-on-the-use-of-drones-for-targetedkilling/oral/27633.html

${ }^{89}$ Nils Melzer, "Interpretive Guidance on the Notion of Direct Participation in Hostilities Under International Humaniatrian Law," International Committee of the Red Cross, vol. May, 2009, 5; 51-53, https://www.icrc.org/en/doc/assets/files/other/icrc-002-0990.pdf.

${ }^{90}$ Larisa Brown, "Defence Secretary Is Accused of Dreaming up a Netflix-Style Plot by Threatening to 'Eliminate' UK Jihadis before They Can Return to Britain," Mail Online, December 6, 2017, https://www.dailymail.co.uk/news/article-5153613/Gavin-WilliamsonBrits-fighting-be.html [Retrieved 24 October 2018].

${ }^{91}$ BBC, "British IS Fighters 'Must Be Killed', Minister Says,” BBC News, 2017, https://www.bbc.co.uk/news/uk-politics-41717394 [Retrieved 24 October 2018].

${ }^{92}$ Belkis Wille, "Unfair ISIS Trial in Iraq Hands Women Harshest Sentences," Human Rights Watch, February 21, 2018, https://www.hrw.org/news/2018/02/21/unfair-isis-trial-iraqhands-women-harshest-sentences.

${ }^{93}$ Vikram Dodd and Esther Addley, "Shamima Begum May Have Criminalised Herself - Senior Terrorism Officer," The Guardian, February 15, 2019 p. 8.

${ }^{94}$ These include the changing situation on the ground in Syria and Iraq, a spate of I.S. inspired terrorist attacks in western Europe, and the Trump administration's relaxation of the rules of engagement with regard to airstrikes in I.S. territory (interestingly, a campaign that US Secretary of Defense, James Mattis, started in 2017 to call a "war of annihilation"). Borger World, J. "US air wars under Trump: increasingly indiscriminate, increasingly opaque" The Guardian. January 23, 2017, p. 23.

${ }^{95}$ Ludovica Iacconi, "Was Sally Jones's 12-Year-Old Son a Legitimate Target? US Drone Strike on Isis 'white Widow' Questioned," International Business Times, October 16, 2017, https://www.ibtimes.co.uk/was-sally-joness-12-year-old-son-legitimate-target-usdrone-strike-isis-white-widow-questioned-1642991. 